\title{
Effect of the type of milking on mammary gland examination in Saanen goats
}

\section{Efeito do tipo de ordenha sobre o exame da glândula mamária de cabras Saanen}

\author{
Jean Silva Ramos ${ }^{1, *}$ (1) (https://orcid.org/0000-0002-9159-3563) \\ Viviani Gomes' (1) (https://orcid.org/0000-0002-4553-2276) \\ Mariana Porto Matazo' (1) (https://orcid.org/0000-0002-8936-4227) \\ Cynthia Pereira da Costa e Silva' (1) (https://orcid.org/0000-0002-0406-2028) \\ Vinicius Alvim Passos Baldacim ${ }^{1}$ (1) (https://orcid.org/0000-0002-3477-1925) \\ Karina Medici Madureira ${ }^{2}$ (1) (https://orcid.org/0000-0002-5821-2722)
}

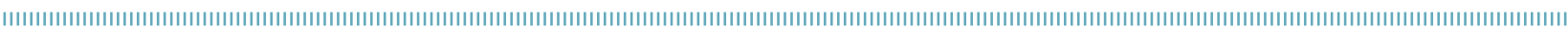

\begin{abstract}
This research evaluated the effect of milking on the physical exam of the mammary gland (MG) and milk examination in Saanen goats. Six properties were selected, four farms were used after evaluation of criteria selection and distributed in two groups according to the milking method: manual or mechanical. The physical examination of MG was performed using the techniques of inspection and palpation, in addition to the examination of the milk by strip cup, California Mastitis Test, somatic cell count, and bacteriological exam. It was possible to detect an association between the milking method with the most of physical exam of the MG: inspection of the MG $(p=0.001)$, inspection of the teat $(p=0.002)$, palpation of the MG $(p=0.054)$ and palpation of the teat $(\mathrm{p}=0.036)$. The machine milking had an association with the reduction of the volume of $\mathrm{MG}(\mathrm{OR}=6.00)$, reduction of the teat size $(\mathrm{OR}=16.19)$, and firm consistency of mammary parenchyma $(\mathrm{OR}=2.39)$. The use of machine milking represented a less risk for an increase of the volume of the $\mathrm{MG}$ volume $(\mathrm{OR}=0.288)$ and the presence of cisternitis $(\mathrm{OR}=0.490)$. The association between the SCC and the type of milking was also detected $(p=0.002)$. Machine milking was associated with changes in the physical exam of MG and milk examination compatible with traumatic lesions. This information indicates inappropriate use of milking equipment in the dairy goat's properties.
\end{abstract}

KEYWORDS: inspection; palpation; California Mastitis Test (CMT); somatic cell count (SCC).
RESUMO: Esta pesquisa avaliou o efeito da ordenha sobre o exame físico da glândula mamária $(\mathrm{GM})$ e do leite em cabras Saanen. Seis propriedades foram selecionadas, quatro fazendas foram utilizadas após avaliação da seleção dos critérios e distribuídas em dois grupos de acordo com o método de ordenha: manual ou mecânico. O exame físico da GM foi realizado utilizando as técnicas de inspeção e palpação, além do exame do leite pelo teste da caneca de fundo escuro, California Mastitis Test, contagem de células somáticas e exame bacteriológico. Foi possível detectar uma associaçáo entre o método de ordenha com a maioria dos exames físicos da GM: inspeção da GM ( $p=0,001)$, inspeção do teto $(\mathrm{p}=0,002)$, palpação da $\mathrm{GM}(\mathrm{p}=0,054)$ e palpação do teto $(\mathrm{p}=0,036)$. A ordenha mecânica associou-se com a redução do volume de $\mathrm{GM}(\mathrm{OR}=6,00)$, redução do tamanho do teto $(O R=16,19)$ e consistência firme do parênquima mamário $(\mathrm{OR}=2,39)$. $\mathrm{O}$ uso da ordenha mecânica representou menor risco para o aumento do volume do volume da GM $(\mathrm{OR}=0,288)$ e presença da cisternite $(\mathrm{OR}=0,490)$. Também foi detectada a associação entre a CCS e o tipo de ordenha $(p=0,002)$. A ordenha mecânica foi associada com as alterações no exame físico de GM e do leite compatíveis com lesôes traumáticas. Essas informaçóes indicam o uso inadequado do equipamento de ordenha na criação de cabras leiteiras.

PALAVRAS-CHAVE: inspeção; palpação; California Mastitis Test (CMT); contagem de células somáticas (CCS). 


\section{INTRODUCTION}

Intensification and technification of dairy goat industry associated with the expansion of the gourmet segment increased the consumption of goat milk and its products, requiring greater control on quality and food safety (SILANIKOVE et al., 2010; LÉRIAS et al., 2014).

The technification of the dairy goat farms has been supporting by the utilization of machine milking, since the manual milking is laborious and slow (BOYAZOGLU; MORAND-FEHR, 2001). Manual milking has also been associated with high somatic cell count (SCC), lower lactose contents and lower milk production, probably due to variations in milk extraction technique among employees, as well as differences in strength and pressure exerted on the teats, causing stress and discomfort, whereas in the mechanical milking method, rhythm and pressure are practically constant (SINAPIS et al., 2007).

Disadvantages to machine milking have also been reported, especially when it is used improperly. The action of vacuum present in the milking system can promote congestion and swelling of the mammary tissue, since it compromises the removal of the interstitial fluids accumulated on the teats by the lymphatic vessels (PAULRUD et al., 2005). Furthermore, machine milking can increase the temperature near the teat sphincter up to $6.6^{\circ} \mathrm{C}$ (ALEJANDRO et al., 2014b).

Excessive vacuum, failure or absence on the pulse, inappropriate pulsation rate and intervals between milking shorter than $10 \mathrm{~h}$ increase the intensity of tissue damage and reduce the strength of the teat channel by compromising the physical defense mechanism (LU et al., 1991; ALEJANDRO et al., 2014a). In addition, the lack of hygiene in the milking process represents a risk factor for caprine mastitis (WÓJTOWSKI et al., 2006; GOMES et al., 2014).

The hypothesis of this research is that the milking method can directly affect the mammary gland health and goat milk quality. The objective of this work was to evaluate the effect of the milking type on the physical examination of udder and milk of Saanen goats.

\section{MATERIAL AND METHODS}

The management of the animals and the samples collection were approved by the Bioethics Commission of Faculdade de Medicina Veterinária e Zootecnia from Universidade de São Paulo under number 827/2006.

Initially, 266 udder halves were analyzed from 133 adults Saanen goats, multiparous and in full lactation from six dairy herds located in São Paulo, Brazil. Three herds had a mechanical milking system, and the others three adopted the manual method for milk extraction. However, one farm of the machine milking group presented so many different conditions from the other farms that it was excluded from the analysis. In the same way, one farm from the manual method group was excluded because there were different aspects and low number of samples. Thus, four farms were used in this study.

Information about management and care with hygiene at the moment of milking was obtained through epidemiological questionnaires filled out by the research team through visual observation and survey with the employees and owners. These data were previously published by GOMES et al. (2014).

The goats were submitted to physical exam of the mammary gland, performed before the morning milking, using the techniques of inspection and palpation of the udder and teats (ANDERSON et al., 2002). During the visual inspection, the udder and teats were evaluated and the size was classified as normal (score 0), increased (score 1) or decreased (score 2). The palpation of the mammary gland was classified according to its consistency in normal (score 0), normal consistency with nodules (score 1) and firm consistency (score 2). Teats and mammary gland were classified by palpation in normal (score 0 ), thelitis (score 1 ) and cisternitis (score 2) (BLAGITZ et al., 2014).

Sequentially to physical exam of the mammary gland, the strip cup test and California Mastitis Test (CMT) were performed. For the CMT, the amount of $2 \mathrm{~mL}$ of milk was obtained from each udder half in a suitable plate, adding the same amount $(2 \mathrm{~mL})$ of specific reagent. After the homogenization of milk with the reagent, the intensity of the viscosity was analyzed as in preestablished scores: $0,1+$, $2+$ and 3+ (SCHALM et al., 1971). After that, milk aliquots were taken for determination of somatic cell count (SCC) and bacteriological exam.

For SCC, aliquots were collected in plastic vials containing two microtablets of bronopol (2-bromo-2nitropropane-1,3-diol) for electronic counting by flow cytometry (Somacount 300, Bentley Instruments). The SCC was distributed in scores according to the number of cells: $0\left(<0.5 \times 10^{6}\right.$ cells $\left./ \mathrm{mL}\right) ; 1$ $\left(0.5-1.0 \times 10^{6}\right.$ cells $\left./ \mathrm{mL}\right) ; 2\left(1.1-5.0 \times 10^{6}\right.$ cells $\left./ \mathrm{mL}\right)$; and 3 $\left(>5.0 \times 10^{6}\right.$ cells $\left./ \mathrm{mL}\right)$.

For bacteriological exam, milk aliquots were aseptically collected in the early morning milking, after cleaning the teats with paper towels and scrubbing the teats ends with cotton with $70 \%$ ethanol (NATIONAL MASTITIS COUNCIL, 2017). Milk aliquots were cultured in Petri plates containing $5 \%$ ovine blood agar using the seeding method for streaking and incubated $\left(37^{\circ} \mathrm{C}\right.$ for 24 and $\left.72 \mathrm{~h}\right)$. The identification of the non-aureus Staphylococci group was performed by the macroscopic and microscopic evaluation of the colonies, catalase and coagulase tests; RapID identification systems (Remel-Oxoid) were also used for Staphylococcus aureus; and the catalase test and macro and microscopic identification of the colonies were performed for Corynebacterium spp. (GOMES et al., 2014). The results obtained for the microbiological examination were distributed in score 0 (negative) and score 1 (positive). 
The scores attributed to physical exam of mammary gland and milk testing are presented in Table 1.

Statistical analysis was performed using the program Statistical Package for the Social Science (SPSS) version 19.0 (IBM Corporation, Armonk, NY, USA). The parameters related to the specific examination of the mammary gland and milk were qualitative, except the SCC. In this case, the SCC was also transformed into scores for the standardization of the statistical design.

The similarity between the management adopted in the six previously selected properties was determined by the Euclidean distance obtained by cluster analysis (HAIR JUNIOR et al., 2009). For this analysis, information obtained from the epidemiological surveys on the management and hygiene of milking was considered: washing of mammary gland, washing of teats, individual drying of teats, use of predipping, use of postdipping, quantity of milking per day, milking line adoption

Table 1. Categorization in scores of physical exams of the mammary gland and milk of Saanen goats.

\begin{tabular}{|c|c|c|}
\hline $\begin{array}{l}\text { Physical exam/ } \\
\text { Milk exam }\end{array}$ & Description & Scores \\
\hline \multirow{3}{*}{$\begin{array}{l}\text { Inspection of the } \\
\text { udder }\end{array}$} & Normal size & 0 \\
\hline & Higher size & 1 \\
\hline & Lower size & 2 \\
\hline \multirow{3}{*}{$\begin{array}{l}\text { Inspection of the } \\
\text { teat }\end{array}$} & Normal size & 0 \\
\hline & Higher size & 1 \\
\hline & Lower size & 2 \\
\hline \multirow{3}{*}{$\begin{array}{l}\text { Palpation of the } \\
\text { udder }\end{array}$} & Normal consistency & 0 \\
\hline & $\begin{array}{l}\text { Normal consistency and firm } \\
\text { with nodules }\end{array}$ & 1 \\
\hline & Firm Consistency & 2 \\
\hline \multirow{3}{*}{$\begin{array}{l}\text { Palpation of the } \\
\text { teat }\end{array}$} & Normal consistency & 0 \\
\hline & Thelitis & 1 \\
\hline & Cisternitis & 2 \\
\hline \multirow[t]{2}{*}{ Strip cup test } & Negative & 0 \\
\hline & Positive (lumps) & 1 \\
\hline \multirow[t]{4}{*}{ CMT } & Negative & 0 \\
\hline & $1+$ & 1 \\
\hline & $2+$ & 2 \\
\hline & $3+$ & 3 \\
\hline \multirow[t]{4}{*}{ SCC } & $\leq 0.5 \times 10^{6}$ cells $/ \mathrm{mL}$ & 0 \\
\hline & $0.5-1.0 \times 10^{6}$ cells $/ \mathrm{mL}$ & 1 \\
\hline & $1.0-5.0 \times 10^{6}$ cells $/ \mathrm{mL}$ & 2 \\
\hline & $\geq 5.0 \times 10^{6}$ cells $/ \mathrm{mL}$ & 3 \\
\hline \multirow[t]{2}{*}{ Bacteriological } & Negative & 0 \\
\hline & Positive & 1 \\
\hline
\end{tabular}

Adapted from Blagitz et al. (2014); CMT= California Mastitis Test; SCC $=$ Somatic cell count. and treatment for mastitis during lactation. The alternatives of answers to the above-mentioned questions were qualitative of the "yes" or "no" type. In this analysis, it was observed that two herds were different from the others, being thus, these properties were excluded of the present investigation.

The data obtained for each parameter (scores) are presented in absolute values and frequencies. To verify if the type of milking (dependent variable) was associated with mammary gland physical changes and milk exam, bi-varied tests were performed using the chi-square test $(\mathrm{p}<0.05)$, then some of logistic regression models was applied to obtain the odds ratio. The SCC was also analyzed by the Kolmogorov-Smirnov normality test, followed by the comparison between the groups by the Mann-Whitney test $(\mathrm{p}<0.05)$.

\section{RESULTS}

Two of the six previously selected herds were excluded from the study because they were different in relation to the others by cluster analysis so that the management could not influence the effect of the milking type in relation to the parameters selected for this research. In this way, the properties continued with the same distribution of groups (manual vs. machine milking), but with a lower sampling: manual milking ( $\mathrm{n}=98$ samples, 49 goats, 2 farms) and machine milking ( $\mathrm{n}=122$ samples; 61 goats, 2 farms).

The frequencies (\%) obtained for the parameters of physical exam of mammary gland and milk in relation to the type of milking are presented in Table 2 .

It was possible to detect the association between the type of milking with the majority of the parameters evaluated in the physical exam of and mammary gland and milk: inspection of the mammary gland $(\mathrm{p}=0.001)$, inspection of the teats $(\mathrm{p}=0.002)$, palpation of the mammary gland $(\mathrm{p}=0.054)$, palpation of the teats $(\mathrm{p}=0.036)$ and SCC scores $(\mathrm{p}=0.002)$. On the other hand, the type of milking was not associated to the strip cup test $(\mathrm{p}=0.092)$, CMT $(\mathrm{p}=0.060)$, and bacteriological examination of milk $(\mathrm{p}=0.186)$ (Table 2).

Logistic regression detected a lower risk for the udder halves with increased volume $(\mathrm{p}=0.001)$ when mechanical milking was adopted (odds ratio, $\mathrm{OR}=0.288 ; 95 \%$ confidence interval, $\mathrm{CI}=0.156-0.533)$. In contrast, this type of milking revealed a greater risk for reduction in the size of mammary gland $(\mathrm{p}=0.006)(\mathrm{OR}=6.0 ; 95 \% \mathrm{CI}=1.686-21.350)$. This phenomenon was also observed for the teats $(\mathrm{p}=0.008)$, obtaining an OR equivalent to $16.190(95 \% \mathrm{CI}=2.089-125.452)$ (Table 2).

In relation to palpation, a greater risk for firm consistency of the mammary gland was observed when mechanical milking was adopted $(\mathrm{p}=0.029, \mathrm{OR}=2.392,95 \%$ 
$\mathrm{CI}=1.096-5.221)$. The lowest risk for cisternitis was observed in mechanical milking $(\mathrm{p}=0.011, \mathrm{OR}=0.490$, 95\% CI $=0.284-0.847$ ).

Considering the SCC, logistic regression showed a higher risk for score $1\left(0.5-1.0 \times 10^{6}\right.$ cells $\left./ \mathrm{mL}\right)$ and score $3\left(>5.0 \times 10^{6}\right.$ cells $\left./ \mathrm{mL}\right)$ when machine milking was adopted, obtaining the $\mathrm{OR}$ equivalent to $2.679(95 \% \mathrm{CI}=1.062-6.758)$ and $5.043(95 \% \mathrm{CI}=1.903-13.367)$, respectively. The quantitative analysis of SCC also showed higher counts in goats subjected to machine milking $\left(0.787 \times 10^{6} \mathrm{cells} / \mathrm{mL}\right)$ when compared to manual milking $\left(0.350 \times 10^{6}\right.$ cells $\left./ \mathrm{mL}\right)$ $(\mathrm{p}=0.001)$.

The majority of the milk samples $(\mathrm{n}=220)$ were bacteriologically negative $(70.9 \%, \mathrm{n}=156)$. The most isolated agent was non-aureus Staphylococci $(\mathrm{n}=58 / 64,90.60 \%)$, followed by Corynebacterium spp. $(\mathrm{n}=3 / 64,4.68 \%)$ and coagulase positive Staphylococci $(\mathrm{n}=3 / 64,4.68 \%)$.

Table 2. Association between the type of milking with the physical exam of mammary gland and milk.

\begin{tabular}{|c|c|c|c|c|c|c|c|c|c|}
\hline Ex & $\mathbf{P}$ & Scores & N/\% & $\begin{array}{c}\text { Machine } \\
\text { milking } \\
\text { N/\% }\end{array}$ & $\begin{array}{c}\text { Manual } \\
\text { milking } \\
\text { N/\% }\end{array}$ & $x^{2}$ & Sig. & $\begin{array}{l}\text { Odds } \\
\text { ratio }\end{array}$ & $\begin{array}{l}95 \% \text { confidence } \\
\text { interval }\end{array}$ \\
\hline \multirow{16}{*}{$\begin{array}{l}\text { Physical } \\
\text { exam of } \\
\text { mammary } \\
\text { gland }\end{array}$} & \multirow{4}{*}{$\begin{array}{l}\text { Insp. } \\
\text { MG }\end{array}$} & 0 & $78 / 35.5$ & $51 / 41.8$ & $27 / 27.6$ & \multirow{3}{*}{0.001 * } & & & \\
\hline & & 1 & $105 / 47.7$ & $37 / 30.3$ & $68 / 69.4$ & & 0.001 * & 0.288 & $0.156-0.533$ \\
\hline & & 2 & $37 / 16.8$ & $34 / 27.9$ & $3 / 3.1$ & & $0.006^{*}$ & 6.000 & $1.686-21.350$ \\
\hline & & Total & $220 / 100$ & $122 / 100$ & $98 / 100$ & & & & \\
\hline & \multirow{4}{*}{$\begin{array}{l}\text { Insp. } \\
\text { teat }\end{array}$} & 0 & $123 / 55.9$ & $63 / 51.6$ & $60 / 61.2$ & \multirow{3}{*}{$0.002 *$} & & & \\
\hline & & 1 & $79 / 35.9$ & $42 / 34.4$ & $37 / 37.8$ & & 0.787 & 1.081 & $0.614-1.904$ \\
\hline & & 2 & $18 / 8.2$ & $17 / 13.9$ & $1 / 1$ & & $0.008^{*}$ & 16.190 & $2.089-125.452$ \\
\hline & & Total & $220 / 100$ & $122 / 100$ & $98 / 100$ & & & & \\
\hline & \multirow{4}{*}{$\begin{array}{l}\text { Palp. } \\
\text { MG }\end{array}$} & 0 & $34 / 15.5$ & $14 / 11.5$ & $20 / 20.4$ & 0.054 & & & \\
\hline & & 1 & $71 / 32.3$ & $36 / 29.5$ & $35 / 35.7$ & & 0.361 & 1.469 & $0.643-3.358$ \\
\hline & & 2 & $115 / 52.2$ & $72 / 59$ & $43 / 43.9$ & & $0.029 *$ & 2.392 & $1.096-5.221$ \\
\hline & & Total & $220 / 100$ & $122 / 100$ & $98 / 100$ & & & & \\
\hline & \multirow{4}{*}{$\begin{array}{l}\text { Palp. } \\
\text { teat }\end{array}$} & 0 & $115 / 52.3$ & $73 / 59.8$ & $42 / 42.9$ & \multirow[t]{2}{*}{$0.036^{*}$} & & & \\
\hline & & 1 & $5 / 2.3$ & $3 / 2.5$ & $2 / 2$ & & 0.875 & 0.863 & $0.139-5.375$ \\
\hline & & 2 & $100 / 45.4$ & $46 / 37.7$ & $54 / 55.1$ & & $0.011 *$ & 0.490 & $0.284-0.847$ \\
\hline & & Total & $220 / 100$ & $122 / 100$ & $98 / 100$ & & & & \\
\hline \multirow{16}{*}{ Milk exam } & \multirow{3}{*}{$\mathrm{SCT}$} & 0 & $216 / 98.2$ & $118 / 96.7$ & $98 / 100$ & \multirow{2}{*}{0.092} & & & \\
\hline & & 1 & $4 / 1.8$ & $4 / 3.3$ & $0 / 0$ & & 0.131 & 1.831 & $1.621-2.067$ \\
\hline & & Total & $220 / 100$ & $122 / 100$ & $98 / 100$ & & & & \\
\hline & \multirow{5}{*}{ CMT } & 0 & $167 / 75.9$ & $92 / 75.4$ & $75 / 76.5$ & \multirow{4}{*}{0.060} & & & \\
\hline & & 1 & $18 / 8.2$ & $10 / 8.2$ & $8 / 8.2$ & & 0.970 & 1.019 & $0.383-2.711$ \\
\hline & & 2 & $19 / 8.6$ & $7 / 5.7$ & $12 / 12.2$ & & 0.137 & 0.476 & $0.178-1.268$ \\
\hline & & 3 & $16 / 7.3$ & $13 / 10.7$ & $3 / 3.1$ & & 0.056 & 3.533 & $0.971-12.857$ \\
\hline & & Total & $220 / 100$ & $122 / 100$ & $98 / 100$ & & & & \\
\hline & \multirow{5}{*}{ SCC } & 0 & $104 / 48.6$ & $46 / 39.7$ & $58 / 59.2$ & \multirow{4}{*}{$0.002^{*}$} & & & \\
\hline & & 1 & $25 / 11.7$ & $17 / 14.7$ & $8 / 8.2$ & & $0.037^{*}$ & 2.679 & $1.062-6.758$ \\
\hline & & 2 & $55 / 25.7$ & $29 / 25$ & $26 / 26.5$ & & 0.308 & 1.406 & $0.730-2.709$ \\
\hline & & 3 & $30 / 14$ & $24 / 20.7$ & $6 / 6.1$ & & $0.001 *$ & 5.043 & $1.903-13.367$ \\
\hline & & Total & $214 / 100$ & $116 / 100$ & $98 / 100$ & & & & \\
\hline & \multirow{3}{*}{ Micro } & 0 & $156 / 70.9$ & $90 / 73.8$ & $66 / 67.3$ & \multirow{2}{*}{0.186} & \multirow{2}{*}{0.301} & \multirow{2}{*}{0.733} & \multirow{2}{*}{$0.409-1.315$} \\
\hline & & 1 & $64 / 29.1$ & $32 / 26.2$ & $32 / 32.7$ & & & & \\
\hline & & Total & $220 / 100$ & $122 / 100$ & $98 / 100$ & & & & \\
\hline
\end{tabular}

Ex $=$ Exam; $P=$ Parameters; Insp. $M G=$ Inspection of the mammary gland; Insp. Teat = Inspection of the teat; Palp. MG = Palpation of the mammary gland; Palp. Teat $=$ Palpation of the teat; $\mathrm{SCT}=$ Strip cup test CMT = California Mastitis test SCC = Somatic cell count; Micro = microbiological exam . $\mathrm{X}^{2}=$ chi-square test; ${ }^{*}$ Significant statistical difference when $\mathrm{p}<0.05$; Odds ratio $<1.0$ indicates lower risk; Odds ratio $>1.0$ indicates higher risk. 


\section{DISCUSSION}

This study found that the type of milking influenced the physical parameters of the mammary gland and characteristics of Saanen goat milk.

Machine milking increased the odds ratio for decreasing the size of the MG and teats, for firm consistency of mammary gland and increased cellularity. Such changes may be compatible with traumatic injuries caused by the milking equipment or intramammary infections from previous lactations, which together with the absence of systematic application of prevention programs can promote irreversible damage to the mammary gland parenchyma. Injuries during the grazing, confinement or feedings may also be related (PERRIN; BAUDRY, 1993).

In the case of intramammary infection, the microorganisms that manage to overcome the physical barrier (teat channel) reach the cistern of the gland and find the neutrophils and macrophages, which at first try to phagocytose them. Toxins, enzymes and components of the bacterial wall (chemotactic factors) stimulate the production of chemical mediators of inflammation (histamine, serotonin and interleukins), recruiting neutrophils from the circulation to the site of infection. This influx of neutrophils causes an inflammatory reaction, by the production of reactive oxygen species and degranulation, resulting in the elimination of the infection, but also damaging the tissue that evolves to fibrosis, damaging the mammary gland function (PAAPE; CAPUCO, 1997).

Fibrosis of the mammary tissue causes loss of alveolar function, causing atrophy with a consequent reduction in volume and change in the consistency of the mammary gland, as identified in this research, in mechanically milked goats, in addition, milk production is compromised (MARNET; MCKUSICK, 2001). Thus, the correct identification of animals compatible with previous or persistent infections on a dairy farm is essential, since these animals become economically unfeasible, compromising their permanence on the farm (MAROGNA et al., 2012).

The maintenance and proper use of mechanical milking are critical to reduce some injuries. High-vacuum level in the teat cup, expired rubbers, incorrect coupling and uncoupling of teat cups can traumatize the orifices of teat sphincter (WÓJTOWSKI et al., 2006), and can often lead to mucosal hyperplasia and consequent loss of the first physical barrier of the mammary gland (PAAPE; CAPUCO, 1997). Furthermore, the pain and discomfort caused by improper milking compromises the milk ejection process, increasing the possibility of accumulation of residual milk, reduced milk production (CHAPAVAL, 2009), congestion and edema of the teats (PAULRUD et al., 2005).

LU et al. (1991) evaluated the effects of different vacuum levels on teat cups $(38,45$ and $52 \mathrm{kPa})$, pulsation ratio $(60: 40$, $50: 50$ and $70: 30)$ and pulsation rate $(90,60$ and 120 pulses $/ \mathrm{min})$ on the performance of dairy goats (milking rate $-\mathrm{kg}$ milk/min, milking time, milk production, CMT and SCC). These authors found that the vacuum of 45 to $52 \mathrm{kPa}$, pulsation ratio $60: 40$ and pulsation rate of 90 pulses/min offered the best conditions for the use of machine milking in dairy goats.

According to CHAPAVAL (2009), the vacuum level for goats can vary between $42-51 \mathrm{kPa}$, depending on the milking system used, and the pulsation rate should be $60 \mathrm{pulses} / \mathrm{min}$. SINAPIS et al. (2007) found an increase in the thickness of the teat channel when the vacuum level of the machine milking was higher than $38 \mathrm{kPa}$, increasing the chances of mammary infections after traumatic injuries.

In the case of cows, the recommendation for the use of the medium vacuum level in the teat, according to the Normative Instruction 48 , is $32-42 \mathrm{kPa}$ and a pulsation rate of $50 \mathrm{pulses} / \mathrm{min}$ (BRASIL, 2002). Although these values may vary according to the required milking speed, type of teat cup and type of machine milking used, the knowledge about the correct use of the equipment according to the animal species is an important tool for injury prevention.

As already presented, it was verified that the mechanically milked goats presented SCC values above $1 \times 10^{6}$ cells $/ \mathrm{mL}$ justified by the probable traumatic influence of the milking equipment on the mammary tissue. In both groups studied, some milk samples had scores +2 and +3 for CMT, in addition to the presence of bacteria predominantly from the non-aureus Staphylococci group and increased SCC, thus characterizing the presence of subclinical mastitis. On the other hand, the association with SCC was only verified in the mechanical milking group, just as the values were higher in this group. Thus, some noninfectious factor would also be linked to the increase in SCC in these goats, reinforced by the changes observed in the physical examination of the mammary gland.

LU et al. (1991) found an increase in SCC as the vacuum level of the teat cup increased $(38,45$ and $52 \mathrm{kPa})$, with the value obtained $\left(0.7 \times 10^{6}\right.$ cells $\left./ \mathrm{mL}\right)$ for the highest tested vacuum level, similar to that observed in our research for the mechanical milking group. SINAPIS et al. (2007) verified an increase in SCC when sheep were submitted to a vacuum level of $50 \mathrm{kPa}$ in the teat cups, when compared to the 38 and $44 \mathrm{kPa}$ levels. CRUZ (2007) found that the use of teat cups with automatic valves, in which the vacuum is not stopped manually before removing them, increased the risk of mastitis and SCC in the early lactation.

It is known that many noninfectious factors (PAAPE et al., 2001) may significantly influence the SCC in goats, varying the count up to $48 \%$ (GONZALO, 2005): intrinsic factors, such as time between milking, milking frequency, daily variations, stage and number of lactation, prolificacy, breed, milk yield and contents, physiological status of the udder; and extrinsic factors, such as type of milking, feed, stress, seasonality, farming system (JIMÉNEZ-GRANADO et al., 2014). Data relative to number and stage of lactation of the animals could not be obtained in this study, since this information was not obtained on a regular basis in most of the studied farms. 
Another factor related to SCC increases would be the infection by caprine arthritis-encephalitis virus (CAEV). Although there are divergences in the literature regarding its real influence on the caprine mammary gland, a long-term observational cohort study, lasting 12 years, found that there was no association of CAEV with daily milk production and SCC (KABA et al., 2012).

In this research it was possible to verify the presence of bacterial isolation in $29.1 \%$ of milk samples, with the predominance of nonaureus Staphylococci bacteria group (90.6\%), similar results were obtained by other authors, who reported the prevalence range of $60 \%$ to $93 \%$ (BERGONIER et al., 2003; LEITNER et al., 2011). Nonaureus Staphylococci has been associating with unapparent mastitis in small ruminants, characterized by the absence of clinical manifestations in the mammary gland associated to the presence of bacteria and high
SCC in milk (BERGONIER et al., 2003). In this study, the unapparent mastitis was observed, considering the frequencies of samples with positive CMT (15.9\%) and SCC (39.7\%) higher than 1,000,000 cells/mL of milk (HAENLEIN, 2002).

\section{CONCLUSION}

Inappropriate machine milking promotes traumatic injuries that influence the size and consistency of the mammary gland and teats, as well as somatic cell count. This method of milk extraction guarantees speed and ease of use in the milking process; however, the practices linked to this methodology need to be reviewed for goats in order to reduce their influence on the mammary gland and milk quality.

ACKNOWLEDGEMENTS: Not applicable.

FUNDING: This study was funded by Fundação de Amparo à Pesquisa do Estado de S. Paulo (grant number 11/18502-7).

CONFLICTS OF INTEREST: All authors declare that they have no conflict of interest.

ETHICAL APPROVAL: This study was approved by Bioethics Commission of Faculdade de Medicina Veterinária e Ciência Animal from Universidade de São Paulo under protocol number 827/2006.

AVAILABILITY OF DATA AND MATERIAL: All data generated or analyzed during this study are included in this published article.

AUTHORS' CONTRIBUTIONS: Conceptualization: Ramos, J.S.; Gomes, V.; Madureira, K. M. Data curation: Matazzo, M.;

Baldacim, V.A.P.; Silva, C.P.C. Formal analysis: Ramos, J.S.; Gomes, V.; Madureira, K.M. Methodology: Gomes, V.; Madureira, K.M. Project administration: Gomes, V. Writing - review \& editing: Ramos, J.S.; Gomes, V.; Madureira, K.M.

| | | | | | | | | | | | | | | | | | | | | | | | | | | | | | | | | | | | | | | | | | | | | | | | | | | | | | | | | | | | | | | | | | | | | | | | | | | | | | | | | | | | | | | | | | | | | | | | | | | | | | | | | | | | | | | | | | | | | | | | | | | | | | | | | | | | | | | | | | | | | | | | | | | | | | | | | | | | | | | | | | | | | | | | | | | | | | | | | | | | | | | | | | | | | | | | | | | | | | | | | | | | | | | | | | | | | REFERENCES

ALEJANDRO, M.; ROCA, A.; ROMERO, G.; DÍAZ, J.R. Effects of milk removal on teat tissue and recovery in Murciano-Granadina goats. Journal of Dairy Science, Champaign, v.97, n.8, p.5012-5016, 2014a. https://doi.org/10.3168/jds.2014-7934

ALEJANDRO, M.; ROMERO, G.; SABATER, J.M.; DÍAZ, J.R. Infrared thermography as a tool to determine teat tissue changes caused by machine milking in Murciano-Granadina goats. Livestock Science, Gijón, v.160, p.178-185, 2014b. https://doi.org/10.1016/j. livsci.2013.11.029

ANDERSON, D.E.; HULL, B.L.; PUGH, D.G. Diseases of the mammary gland. In: PUGH, D.G. (ed). Sheep \& Goat Medicine. Philadelphia: Saunders, 2002. chap.13, p.341-358. https://doi.org/10.1016/ BO-72-169052-1/50015-6
BERGONIER, D., CRÉMOUX, R.; RUPP, R.; LAGRIFFOUL, G.; BERTHELOT, X. Mastitis of dairy small ruminants. Veterinary Research, Jouy-en-Josas, v.34, n.5, p.689-716, 2003. https:// doi.org/10.1051/vetres:2003030

BLAGITZ, M.G.; SOUZA, F.N.; BATISTA, C.F.; DINIZ, S.A.; HADDAD, J.P.A.; BENITES, N.R.; MELVILLE, P.A.; LIBERA, A.M.M.P.D. Clinical findings related to intramammary infections in meat-producing ewes. Tropical Animal Health and Production, Lisbon, v.46, n. 1, p. 127132, 2014. https://doi.org/10.1007/s 1 1250-013-0462-8

BOYAZOGLU, J.; MORAND-FEHR, P. Mediterranean dairy sheep and goat products and their quality: A critical review. Small Ruminant Research, Little Rock, v.40, n. 1, p.1-1 1, 2001. https:// doi.org/10.1016/S0921-4488(00)00203-0 
BRASIL Ministério da Agricultura Pecuária e Abastecimento. Instrução normativa $n^{\circ}$ 48. Diário Oficial da União: Brasília, 2002. 7p. Available from: https://www.jusbrasil.com.br/diarios/662524/pg-7-secao-1diario-oficial-da-uniao-dou-de-14-08-2002. Access on: 15 April 2020.

CHAPAVAL, L. Instruções técnicas para uso da ordenha mecânica em cabras leiteiras (Technical release 101). Sobral: Embrapa Caprinos e Ovinos, 2009. 7p. Available from: https://www. embrapa.br/busca-de-publicacoes/-/publicacao/747932/ instrucoes-tecnicas-para-uso-da-ordenha-mecanica-em-cabrasleiteiras. Access on: 10 mar. 2020.

GOMES, V.; MATAZO, M.P.; SILVA, C.P.C.; BALDACIM, V.A.P.; NOVO, S.M.F.; BACCILI, C.C.; MELVILLE, P.A.; BENITES, N.R. Etiology and risk factors for mammary infection of dairy goat from São Paulo State. Semina: Ciências Agrárias, Londrina, v.35, n.5, p. 1439-1449, 2014. https://doi.org/10.5433/1679-0359.2014v35n5p2551

GONZALO, C. 2005. Somatic cell of sheep and goat milks, analytical, sanitary, productive and technological aspects. In: Future of the sheep and goats dairy sector. International Symposium (Zaragoza 2004-10-28). Anais. Brussels: International Dairy Federation. n.3, p.128-133. Special Issue. https://pascal-francis.inist.fr/ vibad/index.php?action $=$ getRecordDetail\&idt $=17209817$

HAENLEIN, G.F.W. Relationship of somatic cell counts in goat milk to mastitis and productivity. Small Ruminant Research, Little Rock, v.45, n.2, p.163-178, 2002. https://doi.org/10.1016/ S092 1-4488(02)00097-4

HAIR JUNIOR, J.F.; BLACK, W.C.; BABIN, B.J ANDERSON, R.E.; TATHAM, R.L. (ed.). Análise multivariada de dados. Translation: Adonai Schlup Sant'Anna. Porto Alegre: Bookman, 2009.

JIMÉNEZ-GRANADO, R.; SÁNCHEZ-RODRÍGUEZ, M.; ARCE, C; RODRÍGUEZ-ESTÉVEZ, V. Factors affecting somatic cell count in dairy goats: a review. Spanish Journal of Agricultural Research, Madrid, v. 12 , n. 1,p.133-150, 2014.https://doi.org/10.5424/sjar/2014121-3803

KABA, J.; STRZAŁKOWSKA, N.; JÓŹWIK, A.; KRZYŻEWSKI, J.; BAGNICKA, E. Twelve-year cohort study on the influence of caprine arthritis-encephalitis virus infection on milk yield and composition. Journal of Dairy Science, Champaign, v.95, n.4, p.1617-1622, 2012. https://doi.org/10.3168/jds.2011-4680

LEITNER, G.; SAPEIRO, S.; KRIFUCKS, O.; WEISBLIT, L.; LAVI, Y.; HELLER, E.D. Systemic and local mammary gland immunity to udder infection in goats by various Staphylococcus species. Small Ruminant Research, Little Rock, v.95, n.2-3, p.160-167, 2011 . https://doi.org/10.1016/j.smallrumres.2010.09.007

LÉRIAS, J.R.; HERNÁNDEZ-CASTELLANO, L.E; SUÁREZ-TRUJILLO, A.; CASTRO, N.; POURLIS, A.; ALMEIDA, A.M. The mammary gland in small ruminants: major morphological and functional events underlying milk production - a review. Journal of Dairy Science, Champaign, v.81, n.3, p.304-318,2014.https://doi.org/10.1017/SOO22029914000235

LU, C.D.; POTCHOIBA, M.J.; LOETZ, E.R. Influence of vacuum level, pulsation ratio and rate on milking performance and udder health in dairy goats. Small Ruminant Research, Little Rock, v.5, n. 1-2, p.1-8, 1991.https://doi.org/10.1016/0921-4488(91)90025-L
CRUZ, A.M. Studies of machine milking in goats. 2007. Thesis Universitat Politècnica de València, Spain, 2007. Original title: Estudios de ordeño mecánico en ganado caprino.

MARNET, P.G.; MCKUSICK, B.C. Regulation of milk ejection and milkability in small ruminants. Livestock Production Science, Rome, v.70, n.1-2, p.125-133, 2001. https://doi.org/10.1016/ S0301-6226(01)00205-6

MAROGNA, G.; PILO, C.; VIDILI, A.; TOLA, S.; SCHIANCHI, G.; LEORI, S.G. Comparison of clinical findings, microbiological results, and farming parameters in goat herds affected by recurrent infectious mastitis. Small Ruminant Research, Little Rock, v. 102, n. 1, p.74-83, 2012. https://doi.org/10.1016/j.smallrumres.2011.08.013

NATIONAL MASTITIS COUNCIL (NMC). Laboratory handbook on bovine mastitis. Wisconsin: NMC, 2017. 148p.

PAAPE, M.J.; CAPUCO, A.V. Cellular defense mechanisms in the udder and lactation of goats. Journal of Animal Science, Champaign, v.75, n.2, p.556-565, 1997. https://doi. org/10.2527/1997.752556x

PAAPE, M.J.; POUTREL, B.; CONTRERAS, A.; MARCO, J.C.; CAPUCO, A.V. Milk somatic cells and lactation in small ruminants. Journal of Dairy Science, Champaign, v.84, p.E237-E244, 2001. Suppl. E. https://doi.org/10.3168/jds.S0022-0302(01)70223-8

PAULRUD, C.O.; CLAUSEN, S.; ANDERSEN, P.E.; RASMUSSEN, M.D. Infrared thermography and ultrasonography to indirectly monitor the influence of liner type and overmilking on teat tissue recovery. Acta Veterinaria Scandinavica, Denmark, v.46, n.137, 2005. https://doi.org/10.1186/1751-0147-46-137

PERRIN, G.G.; BAUDRY, C. Somatic cell counts in goat's milk. Dairy Science \& Technology formerly Le Lait, Paris, v.73, n.5-6, p.489-497, 1993. Original title: Numérations cellulaires du lait de chèvre. https://doi.org/10.1051/lait:19935-648

SCHALM, O.W.; CARROLL, E.J.; JAIN, N.C. (eds.). Bovine mastitis: Physical and chemical tests for detection of mastitis. Philadelphia: Lea \& Febiger, 1971. 128-157p.

SILANIKOVE, N.; LEITNER, G.; MERIN, U.; PROSSER, C.G. Recent advances in exploiting goat's milk: Quality, safety and production aspects. Small Ruminant Research, Little Rock, v.89, n.2-3, p. 1 10124, 2010. https://doi.org/10.1016/j.smallrumres.2009.12.033

SINAPIS, E.; MARNET, P.G.; SKAPETAS, B.; Hatziminaoglou, I. Vacuum level for opening the teat sphincter and the change of the teat end wall thickness during the machine milking of mountainous Greek breed (Boutsiko) ewes. Small Ruminant Research, Little Rock, v.69, n.1-3, p.136-143, 2007. https:// doi.org/10.1016/j.smallrumres.2006.01.003

WÓJTOWSKI, J.; ŚLÓSARZ, P.; BIELIŃSKA, S.; NOWICKI, S.; GUT, A.; DANKÓW, R. Ultrasound image of morphological changes of teat end in sheep caused by machine milking. Archiv fur Tierzucht, Dummerstorf, v.49, p.231-237, 2006. Special Issue. Available from: http://citeseerx.ist.psu.edu/viewdoc/download?doi=10.1 1.622.6977\&rep=rep $1 \&$ type=pdf. Access on: 20 jun. 2020.

This is an open access article distributed under the terms of the Creative Commons license. 